\title{
Meckel Gruber Syndrome diagnosed in two consecutive pregnancies
}

\author{
Yetkin Karasu, ${ }^{1}$ Kahraman Ülker, ${ }^{1}$ Murat Bozkurt, ${ }^{1}$ Servet Gençdal, ${ }^{1}$ Melek Çiçek, ${ }^{1}$ \\ Suat Dede, ${ }^{1}$ Gülnur Özakşit ${ }^{1}$
}

Keywords: Meckel-Gruber syndrome, encephalocele, polycystic kidney, polydactyly, pes equinovarus

\begin{abstract}
Meckel Gruber syndrome is a lethal, autosomal recessive, multisystemic disorder that is associated with a mutation affecting ciliogenesis. In this report, we present two consecutive pregnancies of a woman complicated with MKS. In the first pregnancy with MKS, the amniotic fluid index was under 1 cm with bilateral polycystic fetal kidneys. Postabortion macroscopic examination of the first fetus revealed multiple congenital anomalies including occipital encephalocele, axial polydactyly and pes equinovarus. Ultrasound examination during the second gestation revealed a singleton pregnancy complicated by MKS. There were multiple congenital anomalies including an occipital encephalocele, polycystic and horseshoe shaped kidneys, axial polydactyly, cleft lip and palate.

${ }^{1}$ Department of Obstetrics and Gynecology, Kafkas University School of Medicine, Kars, Turkey
\end{abstract}

\section{Introduction}

Meckel Gruber Syndrome (MKS) is a rare and lethal, autosomal recessive disease first described by the German anatomist Johann Friedrich Meckel in 1822. Although it is classically characterized by the triad of occipital encephalocele, large polycystic kidneys, and postaxial polydactyly, there may be associated multiple anomalies such as oral clefting, genital anomalies, central nervous system (CNS) malformations, including DandyWalker and Arnold-Chiari malformations, and liver fibrosis. ${ }^{1-4}$

In this report we present two consecutive pregnancies of a woman complicated by MKS.

\section{Case Report}

\section{First pregnancy with MKS}

A twenty seven year old woman presented at 18 weeks gestation in her second pregnancy. Physical examination and routine laboratory workup findings were unremarkable. She had a three-year-old healthy male child. Her medical and family histories were unremarkable.

Please cite this paper as: Karasu Y, Ülker K, Bozkurt M, Gençdal S, Çiçek M, Dede S, Özakşit G. Meckel Gruber Syndrome diagnosed in two consecutive pregnancies. Proceedings in Obstetrics and Gynecology, 2014;4(3): Article 7 [ 5 p.]. Available from: http://ir.uiowa.edu/pogl. Free full text article.

Corresponding author: Murat Bozkurt, Assistant Professor, Kafkas Üniversity Kampüsü Sağlık Araştırma ve Uygulama Hastanesi KARS/Turkey. Tel: 905322279072, 905056330044. Fax: 047422514 30. E-Mail: indrmb@yahoo.com

Financial Disclosure: The authors report no conflict of interest.

Copyright: (c) 2014 Karasu et al. This is an open-access article distributed under the terms of the Creative Commons Attribution License, which permits unrestricted use, distribution, and reproduction in any medium, provided the original author and source are credited. 
Ultrasound findings: Fetal biometry confirmed the 18-week pregnancy using biparietal diameter, abdominal circumference and femur length measurements. The amniotic fluid index was less than $10 \mathrm{~mm}$ and bilateral fetal kidneys were polycystic. Parents did not want to proceed with further antenatal diagnostic tests and pregnancy was terminated with induced abortion.

$\begin{array}{lcr}\begin{array}{l}\text { Post-abortion } \\ \text { examination }\end{array} \text { revealed } & \text { macroscopic } \\ \text { multiple } \\ \text { congenital } & \text { anomalies } & \text { including } \\ \text { occipital } & \text { encephalocele, axial } \\ \text { polydactyly and pes equinovarus }\end{array}$
(Figure 1). The kidneys were enlarged, horseshoe shaped and polycystic. Post-abortion findings were consistent with MKS. The parents were informed about MKS and the risk of recurrence.

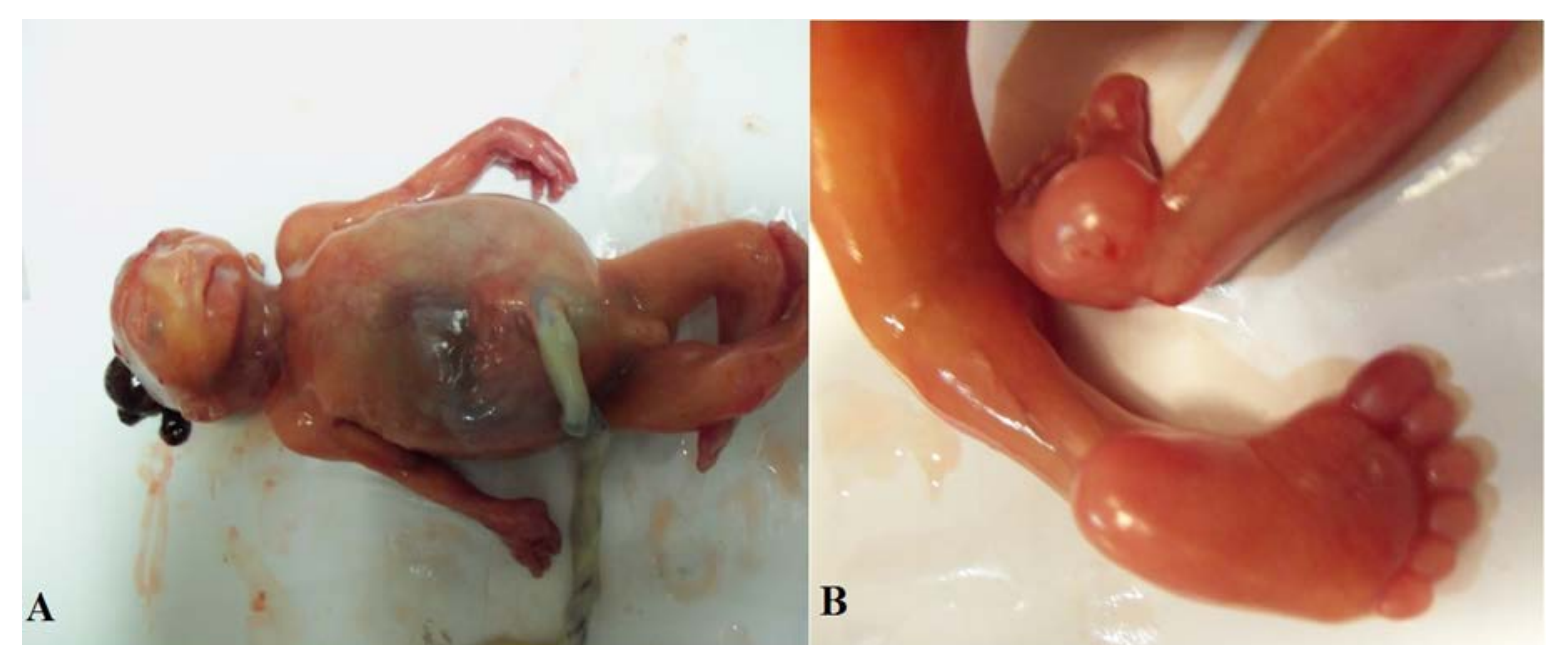

Figure 1. Post-abortion view of the first pregnancy complicated with Meckel Gruber Syndrome.

\section{A: Occipital encephalocele. B: Postaxial polydactyly and pes equinovarus}

\section{Second pregnancy with MKS}

The following year, the woman presented at 20 weeks gestation in her third pregnancy. Her medical, physical and laboratory examinations were unremarkable.

Ultrasound examination revealed a singleton pregnancy complicated with multiple congenital anomalies consistent with MKS again. There were multiple congenital anomalies including an occipital encephalocele, polycystic and horseshoe shaped kidneys, axial polydactyly (Figure 2), cleft lip and palate. The parents refused to proceed with further antenatal diagnostic tests, once again and the pregnancy was terminated with induced abortion. 


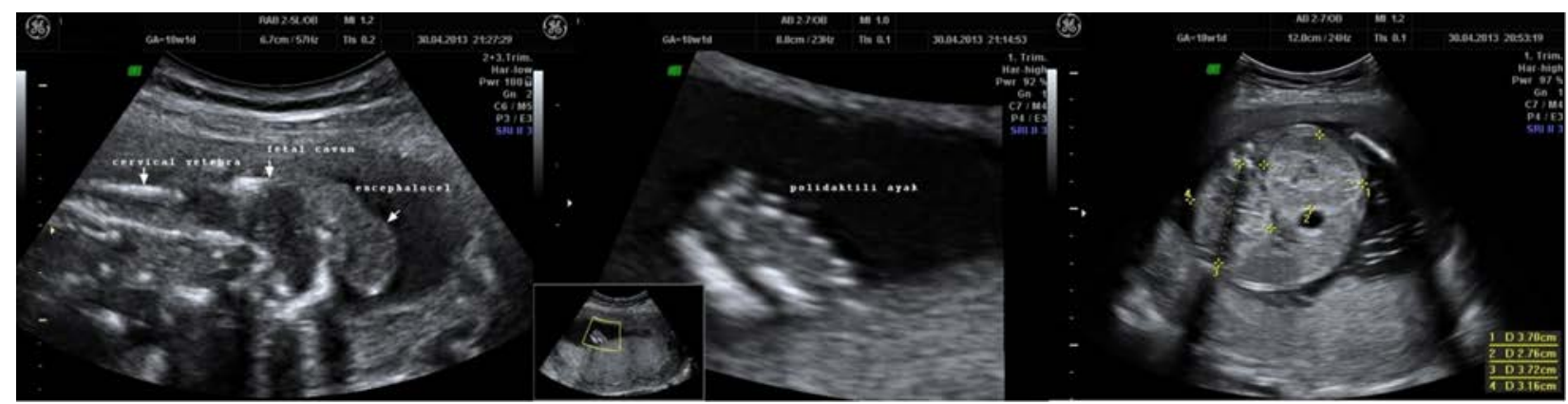

Figure 2. Ultrasound findings of the second pregnancy complicated with Meckel Gruber Syndrome: (From left to right) Encephalocele, postaxial polydactyly and polycystic horseshoe shaped kidneys.

Post-abortion examination confirmed the antenatal ultrasound findings (Figure 3). The woman was discharged

uneventfully and the parents were referred to genetic consultation.
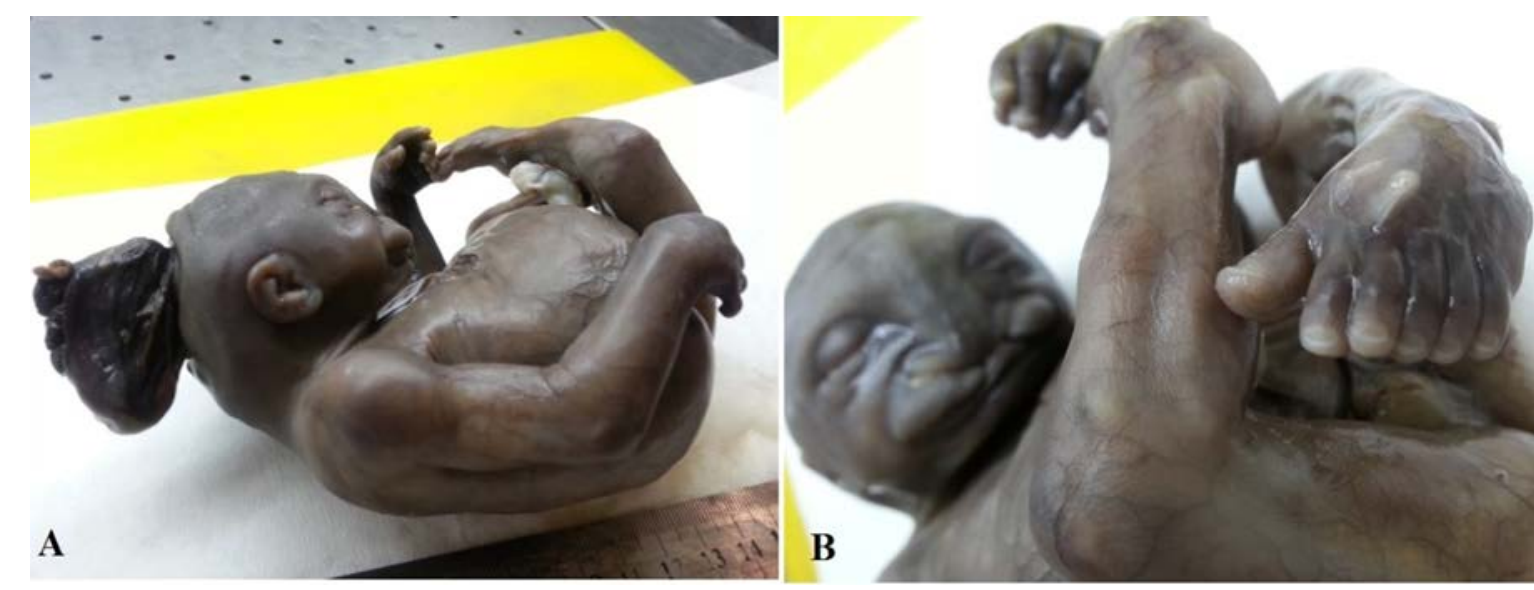

Figure 3. Post-abortion view of the second pregnancy complicated with Meckel Gruber Syndrome demonstrating encephalocele, oral clefting and postaxial polydactyly.

\section{Discussion}

MKS is associated with multiple anomalies; however, it can still be diagnosed antenatally with an ultrasound examination. Its incidence varies from 1 in 13,250 to 1 in 140,000 live births. $^{5}$ Since the disease is transmitted in an autosomal recessive pattern the chance of a subsequent gestation complicated with MKS is $25 \%$.

MKS is associated with multiple anomalies; the major diagnostic criteria include polycystic dysplastic kidneys, occipital encephalocele, or other anomalies of the central nervous system and polydactyly. ${ }^{6}$ Anomalies classified within the minimal diagnostic 
criteria include facial abnormalities, ambiguous genitalia, cardiac septal defects, gastrointestinal anomalies like omphalocele and CNS abnormalities like agenesis of corpus callosum, Dandy-Walker and Arnold-Chiari malformations. ${ }^{4,7}$

In the present case report, occipital encephalocele, bilateral polycystic kidneys with axial polydactyly were present in both of the gestations. In addition to these findings, in the second gestation there was also cleft lip and palate.

MKS is one of a group of inherited disorders, including Joubert Syndrome, NPHP and Bardet-Biedl, that result from defects in the function of cilia and are therefore referred to as ciliopathies. Mutations in at least 10 different genes can result in MKS, making the genetic evaluation of this condition complex and expensive..$^{8,9,10}$

There are many severe malformations present in MKS so early antenatal diagnosis is possible. But since it has an autosomal recessive pattern of transmission, preimplantation genetic diagnosis (PGD) and in vitro fertilization (IVF) or intrauterine genetic analysis can be used. In our case the family has a 3 years old healthy child and they had a very low income. So they did not go further for genetic diagnosis. We think that it is more acceptable to perform genetic analysis after termination of the pregnancy since there are many severe accompanying malformations which are usually incompatible with life. PGD and IVF can be used for families with subsequent effected gestations and those who do not conceive a healthy child.

Although, commonly associated, severe oligohydramnios decreases the clarity of the ultrasound images, in most cases the components of the entity can be determined by early ultrasound findings at 11-14 weeks gestation. $5,11,12$

Differential diagnosis of the disease is important since there is a risk of recurrence in the subsequent pregnancies as in our case. Since most of the diseases with similar clinical presentations (Trisomy 13, Trisomy 18, Joubert Syndrome, Bardet-Biedl syndrome) have an underlying genetic pathology, neonatal autopsy and genetic analysis are crucial for the final diagnosis. ${ }^{6,13,14}$

\section{Conclusion}

MKS is a lethal disorder and most affected fetuses die during pregnancy or shortly after birth. Thus, antenatal diagnosis provides the chance of early termination of the affected pregnancy. Genetic analysis and confirmation of the diagnosis of MKS is a vital tool that may be used in the counseling of the family for the future pregnancies.

This study was presented at the $12^{\text {th }}$ National Obstetrics and Gynecology Congress, 15-19 May 2014, Antalya, TURKEY

\section{References}

1. Kompanje EJ. Features described and illustrated in 1684 suggesting MeckelGruber syndrome. Pediatr Dev Pathol. $2003 \quad$ Nov-Dec;6(6):595-8. DOI:10.1007/s10024-003-2020-2.

PubMed PMID: 15018464.

2. Sergi C, Adam S, Kahl P, Otto HF. Study of the malformation of ductal plate of the liver in Meckel syndrome and review of other syndromes presenting with this anomaly. Pediatr Dev Pathol. 2000 Nov-Dec;3(6):56883.

http://dx.doi.org/10.1007/s1002400101 04. PubMed PMID: 11000335. 
3. Paavola $P$, Salonen $R$, Baumer A, Schinzel A, Boyd PA, Gould S, Meusburger $\mathrm{H}$, Tenconi $\mathrm{R}$, Barnicoat A, Winter R, Peltonen L. Clinical and genetic heterogeneity in Meckel syndrome. Hum Genet. 1997 Nov;101(1):88-92.

http://dx.doi.org/10.1007/s0043900505 92. PubMed PMID: 9385376.

4. Wright C, Healicon R, English C, Burn J. Meckel syndrome: what are the minimum diagnostic criteria? J Med Genet. $1994 \quad$ Jun;31(6):482-5. doi:10.1136/jmg.31.6.482. PubMed PMID: 8071976.

5. Bolineni C, Nagamuthu EA, Neelala N. Fetal autopsy of Meckel Gruber syndrome-a case report. Fetal Pediatr Pathol. $2013 \quad$ Oct;32(5):387-93. doi:10.3109/15513815.2013.768741. Epub 2013 Feb 27. PubMed PMID: 23445452.

6. Alexiev BA, Lin X, Sun CC, Brenner DS. Meckel-Gruber syndrome: pathologic manifestations, minimal diagnostic criteria, and differential diagnosis. Arch Pathol Lab Med. 2006 Aug;130(8):1236-8. PubMed PMID: 16879033.

7. Ahdab-Barmada M, Claassen D. A distinctive triad of malformations of the central nervous system in the MeckelGruber syndrome. J Neuropathol Exp Neurol. 1990 Nov;49(6):610-20. http://dx.doi.org/10.1097/00005072199011000-00007 PubMed PMID: 2230839.

8. Leightner $\mathrm{AC}$, Hommerding $\mathrm{CJ}$, Peng $Y$, Salisbury JL, Gainullin VG, Czarnecki PG, Sussman CR, Harris $P C$. The Meckel syndrome protein meckelin (TMEM67) is a key regulator of cilia function but is not required for tissue planar polarity. Hum Mol Genet. 2013 May 15;22(10):2024-40. doi: 10.1093/hmg/ddt054. Epub 2013 Feb 7. PubMed PMID: 23393159.

9. Panduranga $\mathrm{C}$, Kangle R, Badami R, Patil PV. Meckel-Gruber syndrome: Report of two cases. J Neurosci Rural Pract. $2012 \quad$ Jan;3(1):56-9. doi:10.4103/0976-3147.91943.

PubMed PMID: 22346195.
10. Dawe HR, Smith UM, Cullinane AR, Gerrelli D, Cox P, Badano JL, BlairReid S, Sriram N, Katsanis N, AttieBitach T, Afford SC, Copp AJ, Kelly DA, Gull K, Johnson CA. The MeckelGruber Syndrome proteins MKS1 and meckelin interact and are required for primary cilium formation. Hum Mol Genet. 2007 Jan 15;16(2):173-86. Epub $2006 \quad$ Dec 21. http://dx.doi.org/10.1093/hmg/ddl459. PubMed PMID: 17185389.

11. Sepulveda W, Sebire NJ, Souka A, Snijders RJ, Nicolaides KH. Diagnosis of the Meckel-Gruber syndrome at eleven to fourteen weeks' gestation. Am J Obstet Gynecol. 1997 Feb;176(2):316-9.

http://dx.doi.org/10.1016/S00029378(97)70491-5. PubMed PMID: 9065174.

12. Mittermayer C, Lee A, Brugger PC. Prenatal diagnosis of the MeckelGruber syndrome from 11th to 20th gestational week. Ultraschall Med. 2004 Aug;25(4):275-9. http://dx.doi.org/10.1055/s-2004813057. PubMed PMID: 15300501.

13. Consugar MB, Kubly VJ, Lager DJ, Hommerding CJ, Wong WC, Bakker E, Gattone VH 2nd, Torres VE, Breuning $\mathrm{MH}$, Harris PC. Molecular diagnostics of Meckel-Gruber syndrome highlights phenotypic differences between MKS1 and MKS3. Hum Genet. 2007 Jun;121(5):591-9. Epub 2007 Mar 22. http://dx.doi.org/10.1007/s00439-0070341-3. PubMed PMID: 17377820.

14. Salonen R, Paavola P. Meckel syndrome. J Med Genet. 1998 Jun;35(6):497-501.

http://dx.doi.org/10.1136/jmg.35.6.497. PubMed PMID: 9643292. 